ISSN: 2757-6485

$2021 \& 2$ (1)

\title{
The Effects on Some Sport Organisations of Coronavirus Pandemic
}

\section{Diyar Farooq Ahmed DALOO ${ }^{1}$ \& Abdullah BINGGÖLBALI ${ }^{2}$ \& Veysel SARIGÜL ${ }^{3}$}

\section{REVIEW}

\section{History}

Received: 23 February 2021

Accepted: 10 April 2021

Published: 16 April 2021

\section{DOI: $\underline{\text { http://dx.doi.org/10.29228/anatoliasr.6 }}$}

\section{Authors Communications \\ 1- (Corresponding Author) Health Sciences Institute, Firat University, Elazı $\breve{g}$, TURKEY diyar.daloo@gmail.com \\ https://orcid.org/0000-0003-3923-3584 \\ 2- Teacher, Ministry of Education, Elazı $\breve{g}$, \\ TURKEY \\ bingolbali@gmail.com \\ https://orcid.org/0000-0003-4935-2480 \\ 3- Teacher, Ministry of Education, Elazı̆ğ, TURKEY \\ vyslsrg179@gmail.com \\ https://orcid.org/0000-0002-4083-9076}

\section{Acknowledgement}

All authors contributed to the conception and design of the study.

\section{Funding}

This study received no specific financial support.

\section{Competing Interests}

The authors declare that they have no conflict of interests.

\section{Transparency}

The authors confirm that the manuscript is an honest, accurate, and transparent account of the study was reported; that no vital features of the study have been omitted; and that any discrepancies from the study as planned have been explained.

\section{Ethical}

This study follows all ethical practices during writing.

\section{Citation}

Daloo, DFA., Bingölbalı, A., Sarıül, V. (2021). The Effects on Some Sport Events of Coronavirus Pandemic, Anatolia Sport Research, 2(1): 1-7.

Copyright $(C 2020$ by Anatolia Sport Research

\begin{abstract}
Aim: Sport is an important part of individual life. The sports sector, like the rest of the sectors and human activities, was negatively affected by the Corona pandemic. The purpose of this study is to examine the effectiveness of the COVID-19 pandemic to sports organizations around the world.

Material and Method: The COVID-19 has affected international sports events on all continents. Results in the world's health, education, money and trade institutions and sports activities are similar. Some sporting events such as Tokyo 2020 Olympics Game, Euro 2020 have been canceled or postponed.

Results: As a result of this study, it was seen that the effects of this epidemic on all sports industries in the world are still enormous.

Conclusion: The conclusion of this study turns out that the deadly epidemic has negatively affected the public sectors and sports in particular such as "European Football Championship, Copa America Championship, Olimpic Games, Football leagues and other activities in all countries of the world. It was determined that there is a decline in sports in all countries of the world, especially in countries that practice true professionalism. It has also been found to have an impact on the race to contract over a million professionals.
\end{abstract}

Key Words: Coronavirus, Covid-19, Organisation, Sport Event. 


\section{INTRODUCTION}

In this paper, we offer a short commentary piece on Covid-19's effect on sports events. In doing so, we identify and discuss some areas where the effect has had severe consequences on how the sport is consumed, accessed, and governed. The covid-19 pandemic declared on 11 March 2020. It has affected international locations on all continents (Van Der Hoek et al., 2004). It is a deadly disease with a simple reproductive value (R0) of 2.2, and proof of viral shedding from asymptomatic infected people, besides reported cases are truly underestimated given the shortages or unavailability of check kits in many countries (Holmes, 2003; Van Der Hoek et al., 2004; WHO, 2019; Devecioğlu et al., 2020; Novel, 2020).

The Coronavirus (COVID-19) Pandemic has caused the biggest disruption in the global mathematical calendar since. All over the world to varying degrees, sporting events were canceled or postponed. The spectators do not have games to watch and players do not have games to play. As a result, players are encouraged to "play for humanity" rather than focus on points. For example, former soccer player Craig Foster uses his relationship in the sports world to create a voluntary workforce for charities that help those in need. Only a few countries, such as Turkmenistan, Belarus, Nicaragua, and Tajikistan, have continued professional sports matches as planned (WHO, 2019). The COVID-19 pandemic has a major impact worldwide in terms of public health, economic activities, employment, and social life. In order to stop the spread of COVID-19, various measures were introduced in the world, depending on the epidemic stage and other specific circumstances. In cooperation with the public authorities, there were clear immediate reactions from the sports sector. The sports sector has contributed to preventing the spread of the virus in the early stage of the disease outbreak, through measures that define the various stakeholders involved, including sports organizations, clubs, athletes, coaches, sports personnel, and volunteers, as well as spectators and citizens. At the same time, the sports sector can be severely epidemic, including in economic terms. The epidemic of COVID-19 has severe consequences for the sector to include all levels, especially for sports organizations and clubs, tournaments, fitness centers, athletes, coaches, sports coaches, sports volunteers, and sports-related businesses, including sports event organizers, sports, and the media. Health measures for health authorities with a social divergence have consequences for anti-doping organizations, which hinders them from conducting doping control. This can have an impact on the potential to protect the integrity of sport. This growing concern relates to the global spread of the virus to formal decisions to cancel or postpone sporting events and competitions around the world. In the field of sport, and in light of their national conditions, and due to the impact of the COVID-19 pandemic, countries in the world should be taken various measures to support the sports quarter and motivate citizens to keep bodily activity.

The purpose of this study is the impact of the COVID-19 crisis on sporting organisations/events in the world. The pandemic has effected on the international sports events. The consequences it preserves to ripple on the world institutions and sports activities are similar. Some sports events in world was canceled or postponed to other time after end deadly disease.

\section{Coronavirus "COVID-19" Pandemic and 2020 Tokyo Olympics Games}

The Summer Olympics 2020 is officially known as the 32nd Olympics, known as Tokyo 2020. After a strong competition by a group of participating cities such as (Madrid - Spain, Turkish - Istanbul, and Tokyo - Japan) for the purpose of obtaining the hosting of the thirty-second Olympic Games of the year 2020, where the Japanese city of Tokyo win the hosting the international event and it was called Tokyo 2020. This is the fourth time that Tokyo hosts the Summer Olympics after the Tokyo Games 1964, Sapporo 1972, and Nagano 1998. In this version, some new and mixed sports have been added to 
the two sexes. Tokyo 2020 was scheduled for events from July 24 to August 2020, but due to the pandemic of the Coronavirus (Covid 19), the International Olympic Committee decided to postpone the Tokyo Olympics to at least the year 2021, based on current conditions and according to information provided by the World Health Organization (WHO) regarding the epidemic (Covid 19). This is the first time that the start of the activities of the European session has been postponed due to the global health emergency, as some previous Olympic sessions were canceled due to the global wars. On May 21, 2020, the International Committee of the Red Cross (ICRC) president declared that the session could be canceled if it had not been prepared in the summer of 2021 (Vaishya, 2020; Karakaya and Devecioğlu, 2015; Nicolaet al., 2020).

\section{Coronavirus "COVID-19" Pandemic and International Sports Events}

The consequences of COVID-19 preserve to ripple via the world's health, educational, monetary, and business institutions and sports activities is similar. Some sports events are being canceled or postponed such as Copa America, the 2020 Tokyo Olympics Game, Euro 2020, etc. There are many questions about the situation such as "How do you simultaneously manage fan expectations, minimize operational disruption, and plan for a destiny that, in both the quick and long term, won't look anything just like the past?" Since pandemics likely to be with us for some time, the entire sports ecosystem will want new approaches to cope with threats to financial and commercial enterprise (WEB1, Parnell et al., 2020).

\section{Coronavirus "COVID-19" Pandemic and Copa America Cup}

Besides, the Football Association of South America announced that Copa America was postponed due to the spread of the Coronavirus. The tournament was supposed to be held in Colombia and Argentina between June 12 and July 122020 with the participation of 12 teams, but it will follow in the footsteps of the European Championship, which was also postponed for one year due to the outbreak of the virus (Lopez and La Vanguardia, 2020). The President of the South American Federation added, "It was not easy to make this decision, but the safety of our players and all the people who are part of the large soccer family in South America must be preserved throughout. "I have no doubts that the oldest international tournament in the world will come back stronger in 2021." The Copa America is one of the most important tournaments, with prominent players such as Lionel Messi, Neymar, Sergio Aguero, Luis Suarez, and James Rodriguez participating. The European Championship 2020, which was to be held at the same time in 12 European cities, was postponed for one year and will be held during the same period as Copa America. This year, a copy of Copa America was to be held in two countries for the first time in its 104-year history, with the Northern Group to be based in Colombia and South America in Argentina. In addition to the ten countries on the continent, Australia and Qatar will also participate in the championship. The northern group includes Colombia, Brazil, Ecuador, Venezuela, Peru, and Qatar, while the southern group includes Argentina, Bolivia, Uruguay, Paraguay, Chile, and Australia. According to Reuters (WEB2). The tournament would begin in Buenos Aires on June 12, while the final will be held in Barranquilla, Colombia on July 12. The 2020 version is the fourth in six years, but the universe is on its way to follow the European Championship approach, as this year's championship would have become the last until 2024, to be held every four years. Brazil won the title last year for the ninth time in its history (WEB3).

\section{Coronavirus "COVID-19" Pandemic and Euro 2020}

On the other hand, it was announced that the Euro2020 European Championship would be postponed from 2020 to the summer of 2021, will be held between June 11 and July 11, 2021. The 
Norwegian federation was the first to tweet via its Twitter account, announcing the postponement of "Euro 2020" which was scheduled 2020 to 2021, as it will start on June 11, and end on July 11, with the same system. Hosting 12 previously selected countries. The local federations approved the proposal during a video conference, among the 55 member states, in the presence of club representatives, competition links, and players (Parnell et al., 2020).

This decision comes to make room for all European countries to follow the season's matches locally, after the league stopped due to the spread of the Coronavirus in the "old" continent, as in the event of an end to the virus outbreak, the patrol wheel will return at the beginning of May, and end in a month. The European Football Association showed on Thursday (April 23) that the next European Championship will retain the title of Euro 2020 no matter being postponed until 2021. After the video meeting of the Executive Committee of the European Football Association, the European Football Association said that keeping the same name will be A way to recall the coronavirus and the tough times that the continent faces this year as a result. In addition, and most importantly, the European Football Association (UEFA) has already produced huge amounts of brands earlier than the championship turned into postponed for a year. "This desire is consistent with the UEFA commitment to making Euro 2020 sustainable and not generating additional portions of waste," she said in a statement (Ekstrand et al., 2020; WEB4; WEB5).

\section{Coronavirus Pandemic "COVID-19" and Other Sports Organisation}

The European Football Championship is one of the big sports occasions in the world. It's miles commendable that the Union of European Football Associations "UEFA" have taken the selection to postpone EURO 2020, on the way to now take place in the summer season of 2021. This is the decision that was undertaken on the 18th March 2020. Sport is an integral part of real life, and it may even be among the most affected by the surrounding events. Therefore, the Coronavirus will certainly have a direct impact on sporting events in the world. The impact of COVID-19 on sports games will take some time. Because the proof base is still growing at the infectious disease transmission in the sports activities. The immediate impact appeared in the countries with the lion's share of infections, countries such as the United States of America, the United Kingdom, China, Iran, and Russia, which started from the beginning in the Chinese city of Wuhan and the authorities in China began taking serious steps to control the virus and restore life to its former, to be imposed a stone Healthy in the whole country, while preventing travel to Wuhan Parnell (Bloch, Halle and Steinacker, 2020).

\section{The Sports Sectors Future after the Emerging Coronavirus "COVID-19” Pandemic}

\section{Some Football Events During and After Coronavirus (Covid-19) Pandemic}

Football activities have stopped at the majority of world country, some of which are illustrated as points below (Mohr et al., 2020):

- In South Korea, the football league season restarted on May 8 after several weeks of postponement,

- Bundesliga resumed its season on May 16 behind closed doors,

- The English Premier League, Italy's Serie A, Spanish La Liga, and Turkey's Super Lig resumed in June 2020.

- The Major League Soccer (MLS) has extended until at least June 8, 2020. 
- The Russian football association said matches would resume from June 21, 2020.

- The Euro 2020 event has been postponed till 2021.

Some Marathons Race During and After Coronavirus (Covid-19) Pandemic

We will talk about how sport races were affected by the Coronavirus (COVID-19) pandemic as well as to cancel or stop and starting dates some international competitions in the important points below (Stansbie et al., 1982; WEB6)

- The London Marathon has been postponed till October 4 from April 26,

- The Boston Marathon firstly postponed for five months, afterwards it cancelled for the primary time in its history.

- Amsterdam, Paris and Barcelona marathons have also been postponed.

- The Tokyo Marathon, become confined to the best 200 elite runners.

Tennis Championships Until and After Coronavirus (Covid-19) Pandemic

The Coronavirus hits in all directions, this time in the world of tennis, where the pro and professional game associations decided to extend the suspension of activities. The Association of Tennis Professionals "ATP" determined to extend the suspension through to July 31, 2020 (including) because of Covid-19 protection measures. - ATP announced thru the official Press Release. The selection became made after close collaboration with Tour members, which means that ATP events: Hamburg European Open (Hamburg), Hall of Fame Open (Newport), Nordea Open (Bastad), Abierto de Tenis Mifel (Los Cabos), J. Safra Sarasin Swiss Open (Gstaad), Plava Laguna (Umag), Tokyo Olympic Games (Tokyo), Trust Atlanta Open (Atlanta) and Generali Open (Kitzbuhel) - Will now not take place as scheduled previous. "Due to persisted uncertainties surrounding the Covid-19 pandemic, we remorse to announce our selection to extend the suspension of the Tour" - Andrea Gaudenzi, ATP Chairman has said. For now, all-tournaments scheduled from 1 August 2020 onward are still planning to happen. A similar replacement at the ATP Tour calendar is expected in mid-June. If everything is going as planned ATP Season has to resume in Washington, DC with Citi Open Open - tournament - scheduled for August 2, 2020, consistent with ATP Calendar (Timpka, 2020; Wu, Graw and Matzarakis, 2020). Some activities and other tennis tournaments have been suspended and are explained in the points below (Wu, Graw and Matzarakis, 2020, WEB7):

The International Tennis Federation (ITF) stated 900 tournaments throughout have been postponed. for example;

- The Wimbledon 2020 cancelled due to COVID-19.

- BNP Paribas Open in Indian Wells 2020 become cancelled.

- Xi'an Open 2020 become cancelled.

- Kunming Open 2020 become cancelled.

- The expert tennis tour - men's and women's - has been suspended till at least the stop of July, with all clay-court tournaments in Europe cancelled.

- The French Open initially scheduled to be played from May 24-June 7. was held in October 2020. 


\section{CONCLUSION}

As a result of this study, it was found that the effects of this pandemic were still very large on all sport sectors in the world. In view of the requirements to lessen the damage of the Corona virus pandemic to athletes and social separation, Therefore, we must focus on some of the points written below. (Kucharski et al., 2020; Wu, Graw and Matzarakis, 2020):

$\checkmark$ The role of game in society and its energy to make contributions to the well-being of citizens within the disaster of COVID-19, specifically through sports activities agencies and the participation of athletes in multiple approaches as high-quality position models 6 , in addition to via the devoted work of coaches the use of innovative, new and bendy tools, platforms and schooling methods must be identified and strengthened.

$\checkmark$ The sports sector activities must be resumed in safe and secure conditions for all parties concerned. The specific measures applied in the sports sector to stop the spread of COVID-19 should be mitigated with caution and progressive, while assessing potential risks to avoid premature containment measures.

$\checkmark$ Each day lifestyles of citizens should be modified as well. Staying and operating from home, social spacing and limited possibilities for everyday physical hobby may be very dangerous to the overall wellbeing of citizens. Full and partial closings have shown that providing opportunities to workout and keep bodily hobby in those unheard-of conditions, at the same time as staying or working from home, is important for physical and mental health.

$\checkmark$ In a time of health crisis, team spirit and mutual expertise in any respect levels - between citizens, the sports movement, the non-public sector, nations and international institutions throughout sectors - are important to maintaining lively and wholesome societies.

$\checkmark$ Reflect on the opportunity and relevance of introducing greater flexibility mechanisms into destiny investment programs in the area of sport, and View and publish more statistics and ordinary updates to athletes approximately the possibilities of assisting the sports area to mitigate the outcomes of the COVID-19 epidemic, including through measures to keep athletes and now not be uncovered to this dangerous pandemic.

$\checkmark$ Launching a dialogue with sports and international federations and countries to speak about the ability.

\section{REFERENCES}

Bloch, W., Halle, M. \& Steinacker, J. M. (2020). Sport in Times of Corona.

Boykoff, J. (2019). The Political History of the Olympics and the Human Rights Thicket. Conn. J. Int'l L., 35, xvii. Devecioğlu, S., Karakaya, Y. E. \& Kaya, O. (2020). Management Strategies and Practices Of Volunteering Activities In Sports Organizations. Journal of Sports and Performance Research, 11(1), 80-93.

Ekstrand, J., Spreco, A., Windt, J. \& Khan, K. M. (2020). Are Elite Soccer Teams' Preseason Training Sessions Associated With Fewer İn-Season İnjuries? A 15-Year Analysis From The Union of European Football Associations (UEFA) Elite Club İnjury Study. The American Journal of Sports Medicine, 48(3), 723-729. 
Sarto, F., Impellizzeri, F.M., Spörri, J., Porcelli, S., Olmo, J., Requena, B., Suarez-Arrones, L., Arundale, A., Bilsborough, J., Buchheit, M. \& Clubb, J. (2020). Impact of Potential Physiological Changes due to COVID-19 Home Confinement on Athlete Health Protection in Elite Sports: A Call For Awareness in Sports Programming. Sports Medicine, 50, pp.1417-1419.

Holmes K. V. (2003). SARS-Associated Coronavirus. New England Journal Of Medicine, 348(20):1948-51.

Karakaya, Y. \& Devecioglu, S. (2015). An Evaluation Of The Economic Commitments By Istanbul And Tokyo, Two Candidate Cities For The Summer Olympics Of 2020. Gymnasium, Xvı (1 (Supplement)). Retrieved from http://gymnasium.ub.ro/index.php/journal/article/view/117

Kucharski, A. J., Russell, T. W., Diamond, C., Liu, Y., Edmunds, J., Funk, S. \& Eggo, R. M. (2020). Centre for Mathematical Modelling of Infectious Diseases COVID-19 working group. Early dynamics of transmission and control of COVID-19: a mathematical modelling study. Lancet Infect Dis, 20(5), 553558.

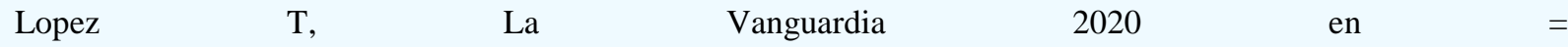
https://www.lavanguardia.com/deportes/20200316/474174038211/coronavirus-covid-19-deporte-

derechos-competiciones-laliga-nba-motogp-formula-1-juegos-olimpicos-tokio.html

https://www.sportanddev.org/en/news-and-views/article-series/covid-19 (Date: 19.01.2020)

Mohr, M., Nassis, G. P., Brito, J., Randers, M. B., Castagna, C., Parnell, D. \& Krustrup, P. (2020). Return to elite football after the COVID-19 lockdown. Managing Sport and Leisure, 1-9.

Nicola, M., Alsafi, Z., Sohrabi, C., Kerwan, A., Al-Jabir, A., Iosifidis, C., Agha, M. \& Agha R. (2020). The SocioEconomic Implications of The Coronavirus and COVID-19 Pandemic: A Review. International Journal of Surgery.

Novel, C. P. E. R. E. (2020). The Epidemiological Characteristics of An Outbreak of 2019 Novel Coronavirus Diseases (COVID-19) in China. Zhonghua Liu Xing Bing Xue Za Zhi= Zhonghua Liuxingbingxue Zazhi, 41(2), 145.

Parnell, D., Widdop, P., Bond, A. \& Wilson, R. (2020). COVID-19, Networks and Sport. Managing Sport and Leisure, 2:1-7.

Stansbie, D., Aston, J. P., Powell, N. H. \& Willis, N. (1982). Creatine Kinase MB in Marathon Runners. The Lancet, 319(8286), 1413-1414.

Timpka, T. (2020). Sport in The Tracks and Fields of The Corona Virus: Critical Issues During The Exit From Lockdown. Journal of Science and Medicine in Sport, 23(7), 634-635.

Vaishya, R. (2020). COVID-19 pandemic and the Olympic Games. Journal of Clinical Orthopaedics and Trauma, 11(Suppl 3), p.S281.

Van Der Hoek, L., Pyrc, K., Jebbink, M.F., Vermeulen-Oost, W., Berkhout, R. J., Wolthers, K.C., Wertheim-van Dillen, P.M., Kaandorp, J., Spaargaren, J. \& Berkhout B. (2004). Identification of A New Human Coronavirus. Nature Medicine, 10(4):368-73.

WEB1. https://www.sportanddev.org/en/news-and-views/article-series/covid-19 (Date: 10.05.2019)

WEB2. http://www.conmebol.com/es/comunicado-oficial-2 (Date: 04.01.2020)

WEB3.https://www.aa.com.tr/en/latest-on-coronavirus-outbreak/euro-2020-postponed-for-one-year-over-covid19/1769252 (Date: 8.01.2020)

WEB4. https://www.uefa.com/insideuefa/mediaservices/mediareleases/newsid=2641071 (Date: 13.01.2020)

WEB5.https://www.goal.com/en/news/coronavirus-vs-euro-2020-why-summer-tournament-is-ingrave/1dvq3vg2550ou1hwvgm6zh3b3z (Date: 15.01.2020)

WEB6. https://www.entrepreneur.com/article/349917 (Date: 17.01.2020)

WEB7. https://inkedin.com/atp-and-wta-suspensions-tennis-news/ (Date: 23.01.2020)

WHO (2019). World Health Organization. Coronavirus disease 2019 (COVID-19). Situation report 43, 3 March, 2019. https://www.who.int/docs/default-source/coronaviruse/situation-reports/ 20200303-sitrep-43covid-19.pdf?sfvrsn=2c21c09c_2.

Wu, Y., Graw, K. \& Matzarakis, A. (2020). Comparison of Thermal Comfort between Sapporo and Tokyo-the case of The Olympics 2020. Atmosphere, 11(5), 444. 